\title{
Study the Effect of Indomethacin Administration on Breast Tumor Growth and Inos Gene Expression in Tumor-Bearing Mice
}

\author{
Soheil Afshari-Behbahanizadeh1, Samad Farashi Bonab²* \\ 1Faculty of veterinary medicine, Azad university of Garmsar, Garmsar, Iran \\ ${ }^{2}$ Immunology department, medical science school, university of Tehran, Tehran, Iran \\ *Corresponding Author E-mail: soheil.afshari1383@gmail.com
}

Received: 4 February 2019, Revised: 19 February 2019, Accepted: 3 March 2019

\begin{abstract}
Breast cancer is a public health concern among the women. iNOS is stated by the effect of various inflammatory factors and is thus called inducible NOS. Investigating iNOS expression is a potent tool for understanding effective molecular parameters in tissue and cellular responses to external factors. In this research study, iNOS expression in mice with breast cancer was investigated and the effects of various doses of indomethacin on the iNOS gene expression in breast tumors was evaluated.

4T1 cells were grown in RPMI 1640 Medium. $200 \mu$ l of cell suspension $\left(10^{7}\right.$ cells) were injected into the mice right flank, subcutaneously. $35 \mathrm{Balb} / \mathrm{C}$ albino mice divided into five groups each group consist of 7 mice. First group was healthy control group, second group was tumor control, and the $3 \mathrm{rd}, 4^{\text {th }}$ and $5^{\text {th }}$ groups were treated by $25 \mu \mathrm{g}, 50 \mu \mathrm{g}$ and $100 \mu \mathrm{g}$ of indomethacin, respectively. The rate of breast tumor growth was measured in treated groups for two months. The levels of iNOS gene expression was determined using real time RT-PCR technique.

Our results demonstrated, iNOS expression in tumor tissue increased with the growth of breast cancer cells. Furthermore, Administration of $25 \mu \mathrm{g}$ and $100 \mu \mathrm{g}$ indomethacin neither had significant effect on breast tumor growth nor effect on iNOS gene expression. While $50 \mu \mathrm{g}$ indomethacin decreased the tumor growth $(\mathrm{P}>0.05)$ and decreased iNOS gene expression.

Further studies such as evaluating the effects of indomethacin on the other anti-tumor immunosuppressing factor and additional tests western blot, flow cytometry and immunohistochemistry recommended in order to obtain more practical findings.
\end{abstract}

Key words: Indomethacin, gene expression, iNOS, breast tumor.

\section{Introduction}

Cancers mortality augmented during the years (Gürsoy et al., 2009), now it is the second cause of death in developed country and in Iran is the third cause of death after cardiovascular diseases and accidents In Iran, breast cancer is the outstanding type of 
cancer accounting about $24.6 \%$ of different types of cancers for females (Jazayeri et al., 2015).

In different kinds of cancers such as breast cancer, colon cancer and melanoma, over expression of iNOS was observed (Cianchi et al., 2003; Granados-Principal et al., 2015; Grimm et al., 2008) while in esophageal cancer the results illustrated that there was no significant difference between iNOS expression in the esophageal cancer group and control groups ( $p$ > 0.05); however, there was an escalation in iNOS expression in the case group. Interestingly, there was a significant difference between iNOS expression in males and females in the two groups of healthy subjects and patients, and it was higher in women than in men (Barani et al., 2016).

Inducible nitric oxide synthase (iNOS) is a pro-inflammatory enzyme which has effects on chronic inflammation and wound healing and it could synthesize Nitric Oxide (NO) (Nathan et al., 1994).

NO is a tiny bioactive molecule with pleotropic effects and has variety of effects on cancer cells and tumors biology such as dose and temporal dependent via the capability to inhibit or motivate cell proliferation, migration and apoptosis. Nitric oxide also has concentrationdependent pro- and anti-tumor effects (Ambs et al., 2011; Burke et al., 2013; Pervin et al., 2007). NO is released by different NOS isoforms such as neuronal (nNOS/NOS1), inducible (iNOS/NOS2) and endothelial (eNOS/NOS3) (Burke et al., 2013) all of which are encoded by separate genes and, therefore, differently regulated. Unlike endothelial NOS and neuronal NOS, iNOS is not expressed constitutively, but is expressed in most cell types given the appropriate stimulatory conditions, which include infection, cytokines, mechanical injury, and hypoxia (Xie et al., 1994).

Generally, neuronal NOS and endothelial-cell NOS produce NO in low concentrations, and they can be induced in neurons and Endocrine cells. Their activity depends on high levels of cytoplasmic calcium/calmodulin. However, iNOS can be produced by neutrophils, macrophages, endothelial cells and other cell type (Nathan et al., 1994).

Research studies showed that stem cell-like tumor properties induced by NO in breast cancer (Ambs et al., 2011). Pro-inflammatory signaling pathways are generally upregulated in breast cancer, nitric oxide synthase-2 (NOS-2) showed as independent predictors of diseases result (Basudhar et al., 2017). Nitric oxide synthase-2 (NOS2) is an inflammation-associated enzyme which has oncogenic function in breast cancer (Basudhar et al., 2017).

The anti-inflammatory drugs have a great potential on increasing the effectiveness of cancer immunotherapy drugs (Hussain et al., 2012). Indomethacin is none steroidal antiinflammatory drugs (NSAIDs) which has harmful effect on gastrointestinal (GI) mucosa (Carrasco-Pozo et al., 2016). Also, Indomethacin has effect on some cancers such as colorectal cancer (Cianchi et al., 2003), skin cancer, head and neck carcinoma, melanoma and B cell lymphoma (Grimm et al., 2008), small cell lung cancer cells and pancreas cancer in vitro (Lange et al., 2011; Okayama et al., 2013). In various studies, indomethacin had anti-cancer activity in inhibition of cell growth, induction of apoptosis and suppression of tumor invasion (Okayama et al., 2013).

Although many studies have been done on different kinds of cancers, little attention has been given, up to now, to the study on the effect of indomethacin on iNOS gene expression. In this paper we aimed to: 1) investigate the effect of various doses of indomethacin on 
iNOS gene expression and 2) assess the tumor growth rate in breast tumors in different doses of indomethacin.

\section{Materials and method}

Breast cancer cell line 4T1 was purchased from Pasteur institute Tehran Iran. Breast cancer cells line were cultured in Roswell Park Memorial Institute (RPMI) medium 1640 (Invitrogen, UK) which is containing 10\% fetal bovine serum (FBS), L-Glutamine, 100 units $/ \mathrm{mL}$ penicillin and $200 \mu \mathrm{g} / \mathrm{mL}$ streptomycin. Cells were maintained in a humidified atmosphere with $5 \% \mathrm{CO} 2$ at $37^{\circ} \mathrm{C}$, with exchange of medium every $48 \mathrm{~h}$.

35 Female Balb/c albino mice (6-7 weeks of age, 14-15 g in weight) were purchased from Pasteur institute Tehran Iran. $200 \mu$ l suspension contain $10^{7}$ cells, mycoplasma free were induced in mice's right flank subcutaneously.

Three weeks after implantation of tumor cells mice with $80-100 \mathrm{~mm}^{3}$ tumor volume were divided into 5 groups each group contain 7 mice. The mice were housed in cages maintained in a regulated environment (12-h: 12-h light/dark cycle) and were supplied with water and food ad libitum. First group was healthy control (to 7 mice), second group was tumor control (to 7 mice) and $3^{\text {rd }}, 4^{\text {th }}$ and $5^{\text {th }}$ were tumor groups which received 25, 50 and100 $\mu \mathrm{g}$ indomethacin, respectively. First the amount of drug were dissolved into distilled water and fed the mice orally for two months. For both healthy and tumor control groups plosive were administrated. The size of tumor were measured with digital caliper $1 / 2\left(\right.$ length $\times$ width ${ }^{2}$ ) in 10, 17, 23, 30 and 37 day after treatment (Figure 1). All institutional guidelines for animal welfare and experimental conduct were followed. All efforts were made to minimize animal suffering. Briefly, the mice with physical approach, cervical dislocation were euthanized. $100 \mathrm{mg}$ of tumor was collected and stored in RNA Later (Behnogen). The biopsy was lysis with Guanidine thiosulfate lysis buffer (KIAzolß, USA).

iNOS mRNA expression was detected in the treated mice and compared with the control mice. cDNA synthesis was performed. The concentration and purity of standard cDNA was determined by Thermo Scientific ${ }^{\mathrm{TM}}$ NanoDrop $^{\mathrm{TM}}$ 2000/2000c.

The primer sequences used for iNOS were forward, 5'-GGAGCGAGTTGTGGATTG-3' and reverse, $5^{\prime}$-CCAGGAAGTAGGTGAGGG-3'. The primer sequences used for $\beta$-actin were forward, 5' -GAAGATCAAGATCATTGCTCC- $3^{\prime}$ and reverse, $5^{\prime}$-CTAAGTCATAGTCCGCCTAG- $3^{\prime}$. For PCR, a two-step RT-PCR kit (Sinagene) was used. Preparation steps of major PCR solution were performed on ice and all tubes were placed on ice. The PCR reactions for iNOS were initiated with a denaturing step at $95^{\circ} \mathrm{C}$ for $3 \mathrm{~min}$, followed by 40 cycles at $95{ }^{\circ} \mathrm{C}$ for $10 \mathrm{~s}, 58{ }^{\circ} \mathrm{C}$ for $10 \mathrm{~s}$, and $72{ }^{\circ} \mathrm{C}$ for $20 \mathrm{~s}$ PCR was performed by a thermocycler machine (Mastercycler gradient, Eppendorf).

Real-time PCR reaction was performed for analyzing iNOS gene expression. $\beta$-actin was used as an internal control gene. SYBR green I was used for performing real-time PCR reaction. The composition and amount of reaction components of real-time PCR were observed. After placing samples in the system for real-time PCR reaction, the system's software was programmed. A fluorescent reporter was used for this method. These reporters are designed in a manner that if they have DNA replication, they should produce light, so increasing recorded light intensity in the device is directly proportional to the amount of obtained product. By continuing PCR, the fluorescent intensity will increase. The first cycle in which the fluorescent is greater than the baseline threshold is called threshold cycle (CT), in other words, in the initial phase of progressive steps, the amount of 
fluorescent increases to reach a threshold, and it is higher than the background level with a known amount, and this cycle is called CT. The CT amount was recorded based on drawing a threshold for all samples. For each sample, three replications were performed and the average CT was calculated for all samples. Information processing in real time PCR is important. The investigate ways were $\Delta \Delta \mathrm{CT}$ method. To reduce errors and correct variations in primer materials in RT-PCR, the approved method is simultaneous RNA amplification, which is used as an internal standard. In this study, data were tested by using the t test in IBM SPSS statistics 22 software significance level set at 0.05 .

\section{Results}

The CTs of the samples were calculated based on the proliferation diagrams after performing reaction on all samples of any concentration using $\beta$-actin protein and their curvature drawn (based on the CT on the y-axis and the log of the copy amount on the $\mathrm{x}$ axis). The efficiency of the reaction for $\beta$-actin was 1.07 and $\mathrm{R}^{2}$ was $98 \%$ after drawing the standard curvature.

The same steps performed for the $\beta$-actin standard curvature were performed for the iNOS standard curvature as well. The efficiency of the reaction for iNOS was $90 \%$ and $\mathrm{R}^{2}$ was $97 \%$ after drawing the standard curvature.

The $\beta$-actin proliferation progression in every cycle was observed. As well as, the progression of iNOS proliferation curvature in every cycle was observed.

One of the most important advantages of real-time PCR is fusion curvature drawing by which we determined the diversity of products in the PCR reaction. In order to draw the curvature the instrument changes the samples temperature in specified durations, then the rate of change is shown on the $\mathrm{y}$-axis and the instrument temperature is shown on the $\mathrm{x}$ axis. In order to draw the curvature, samples temperature increase and the light which was emitted from the samples were measured. There was a sudden drop of florescent light intensity at about $75^{\circ} \mathrm{C}$ was observed.

The fusion curvature was evaluated in order to observe whether or not PCR worked properly. In this curvature the temperature of the samples increases gradually and the emitted light was measured. The PCR product of iNOS begins to open in becoming singlestrand following increasing the temperature of double-strand DNA and dye molecule separate from them. The intensity of fluorescence decreases following increasing the temperature until the temperature reaches around $74{ }^{\circ} \mathrm{C}$, which is the temperature of the PCR reaction product, then the intensity of fluorescence decreases and breaking will appear in the fusion curvature (Figure 4, 5).

Statistical results obtained from the analysis demonstrated, that iNOS gene expression increased in tumor tissue while breast cancer cells were growing.

To ensure amplification of the gene, the samples resulted from PCR amplification, four amplified samples of each gene were randomly chosen and were put on $2 \%$ agarose gel the results obtained from agarose gel image confirmed the correct amplification of iNOS and $\beta$ actin (Figure 3).

In this study, the administration of two doses of indomethacin, $25 \mu \mathrm{g} / \mathrm{mL}$ and $100 \mu \mathrm{g} / \mathrm{mL}$ neither had any significant effect on tumor growth nor effect on iNOS gene expression.

All mice which were treated with $100 \mu \mathrm{g} / \mathrm{mL}$ of indomethacin were died within 14 days after treatment. 
Interestingly, in one hand, $50 \mu \mathrm{g} / \mathrm{mL}$ of indomethacin considerably reduced the iNOS gene expression in treated group in comparison with control group (Figure 2). In the other hand our results demonstrated that, $50 \mu \mathrm{g} / \mathrm{mL}$ of indomethacin decreased tumor growth but this reduction was not significant (Figure 1).

Also the group which was treated with $50 \mu \mathrm{g} / \mathrm{mL}$ indomethacin had longer survival time (about 60 percent of the mice were alive 2 weeks longer).

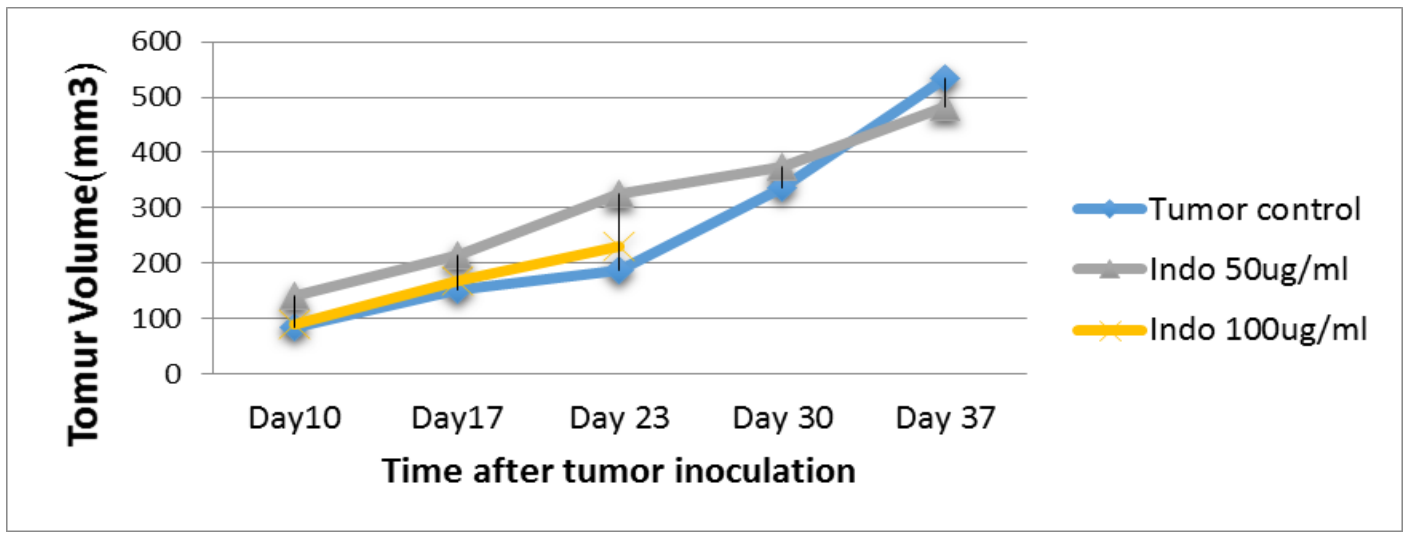

Figure 1. Tumor growth after indomethacin administration in drinking water

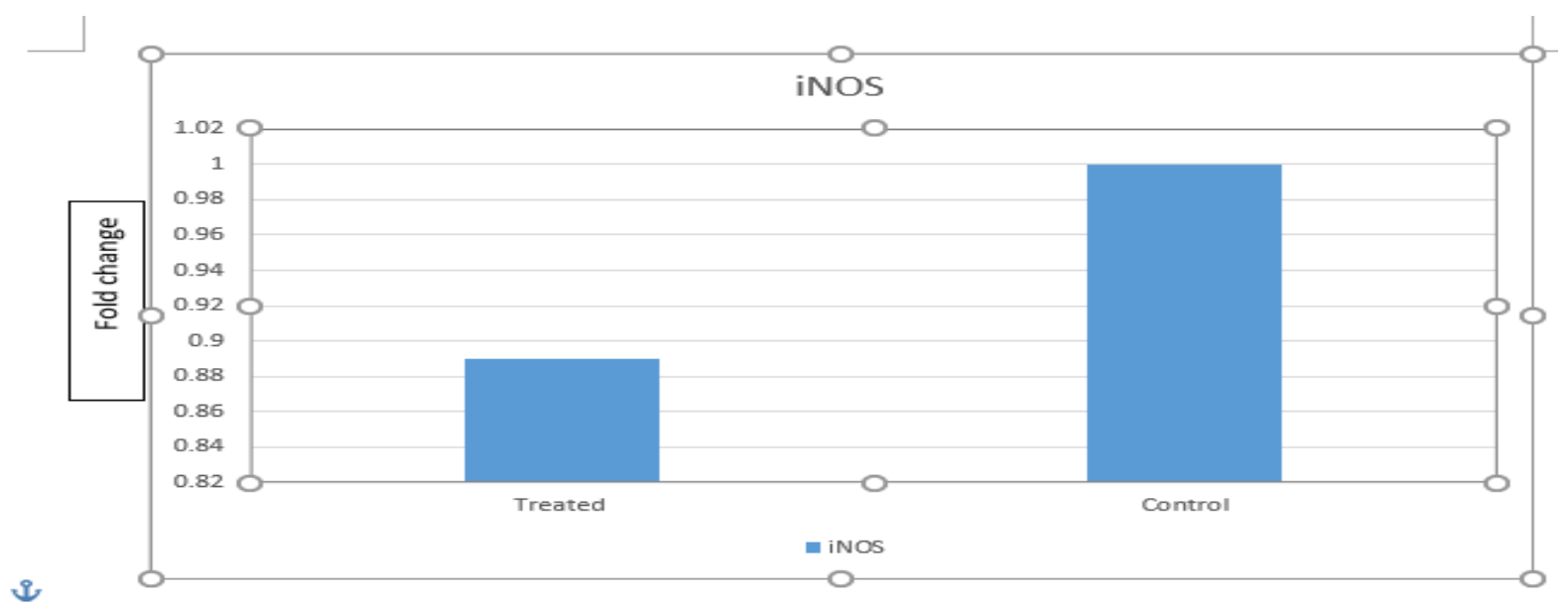

Figure 2. $50 \mu \mathrm{g} / \mathrm{mL}$ indomethacin reduced the expression of the iNOS gene in compared with the control group

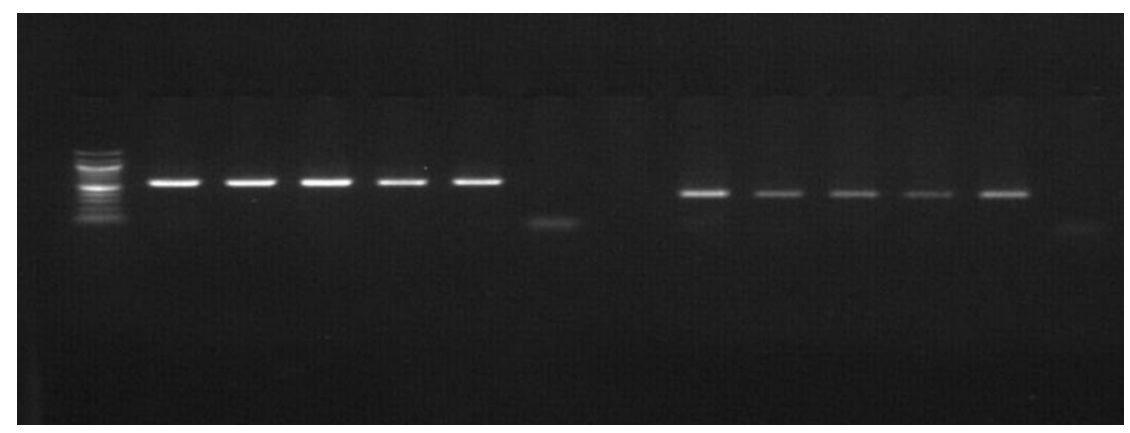

Figure 3. PCR amplification agarose gel image 


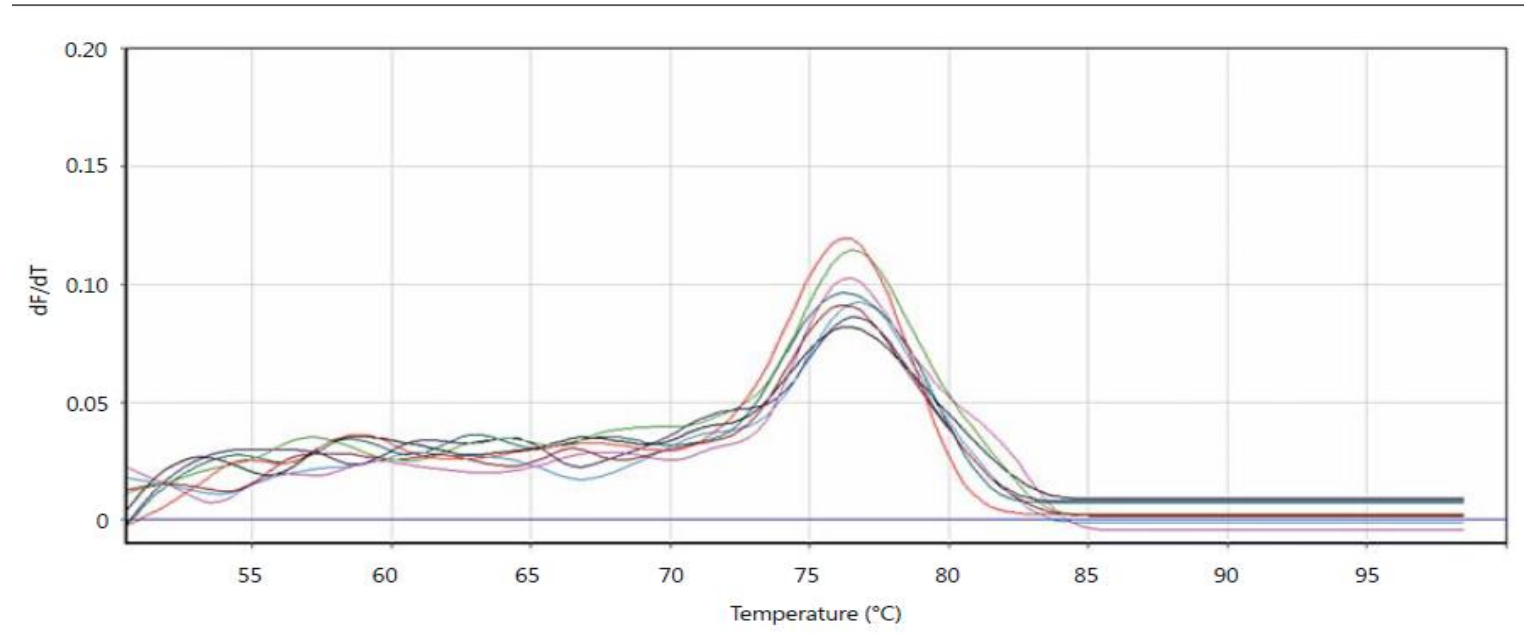

Figure 4. iNOS fusion curvature. $77^{\circ} \mathrm{C}$ was the temperature of iNOS product

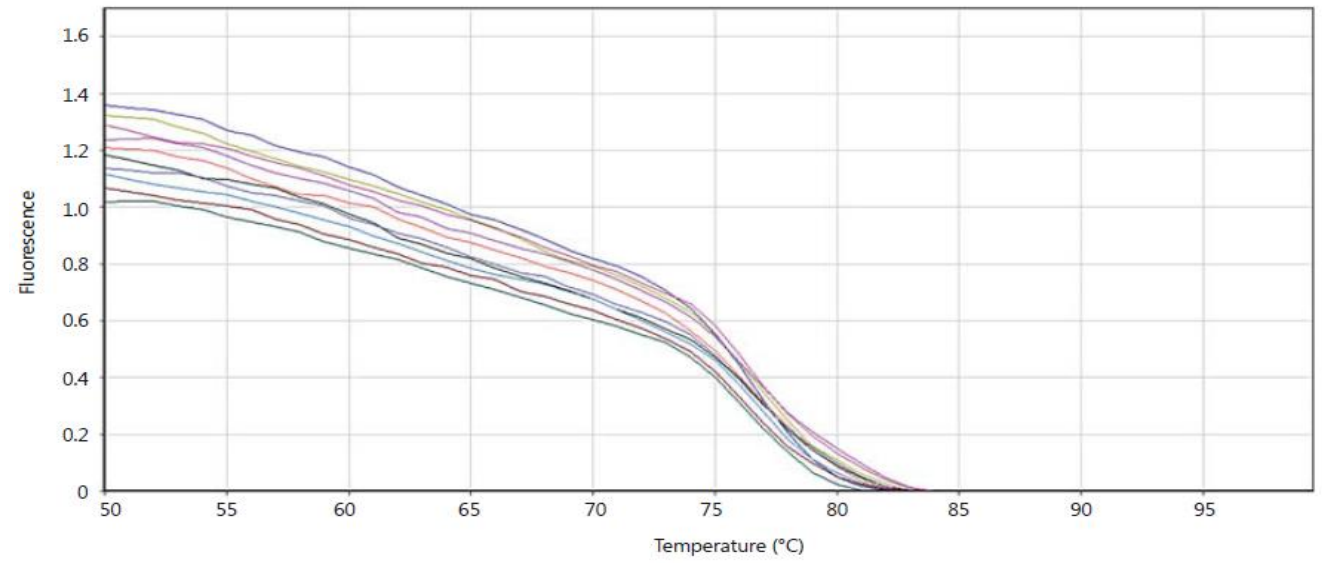

Figure 5. The changes of fluorescence in terms of temperature for iNOS gene

\section{Discussion}

Breast cancer is the predominant cause of mortality among women worldwide (Vahora et al., 2016). In Iran, it is the first leading cause of cancer-related deaths among women (Jazayeri et al., 2015). Despite numerous advances, treatment resistance and metastasis are the main causes of death in patients with breast cancer (Granados-Principal et al., 2015).

Nitric oxide (NO) is a bioactive molecule that exhibits pleotropic effects within cancer cells and tumors, with concentration-dependent pro- and anti-tumor effects. In mammals, NO is synthesized by three different nitric oxide synthase (NOS) isoforms: neuronal (nNOS/NOS1), inducible (iNOS/ NOS2), and endothelial (eNOS/NOS3) (Burke et al., 2013). Increased iNOS expression has been found in breast cancer (Bulut et al., 2005) and other different cancers such as lung (Okayama et al., 2013), colon (Ambs et al., 2011), melanoma (Massi et al., 2001), and glioblastoma (Eyler et al., 2013).

The results of our study showed that iNOS expression increased in breast cancer cells (Figure 3 and Figure 4).

In many tumors, iNOS expression is high, however, the role of iNOS during tumor development is very complex and quite perplexing, with both promoting and inhibiting actions having been described (Vannini et al., 2013). Overexpression of iNOS and 
concomitant changes on cancer cell kinetics were demonstrated to be anti-cancer in potential according to several in vitro and in vivo studies. In animal models of fibro sarcoma tumor progression slowed down upon expression of iNOS via gene transfer demon- strating potential of tumor growth inhibition by iNOS-derived NO. Overexpression by means of other delivery forms of iNOS also produced anti-tumor results (Vannini et al., 2013).

Retroviral delivery of iNOS in mice pro- duced slowly progressing tumors and fewer lung metastases than control mice transfected with iNOS-negative retrovirus (Juang et al., 1997). Increased iNOS activity has been positively correlated with the degree of malignancy in gynecological tumors (Thomsen et al., 1995), gastric cancer, squamous cell carcinoma, hepatocellular carcinoma, melanoma and leukemia (Bonavida, 2010), while high iNOS expression is associated with favorable prognoses in ovarian (Anttila et al., 2007) and lung cancers (Puhakka et al., 2003). Osteosarcoma of the jaw in patients was associated with over expression of iNOS as deduced by immunohistochemical analysis (Chen et al., 2007). Similarly, oral carcinomas and oral hard tissue sarcoma in patients were also associated with iNOS expression. Interestingly, soft tissue oral sarcomas from this study were negative for iNOS expression (Augustine et al., 2015) and iNOS expression in car- cinemas was higher than in sarcomas. In women with estrogen re- ceptor (ER)-negative breast tumors, iNOS expression is an in- dependent marker for prognosis. iNOS positivity related with angio- genesis of tumors (Glynn et al., 2010). In other clinical studies of gastric cancer, iNOS correlated with tumor progression and has potential to be of prognostic value (Li et al., 2005). Low levels of expression of iNOS produced tumors in the pancreas and led to liver metastasis and ascites in mice models while higher levels of iNOS expression did not lead to metastasis. When iNOS expression was inhibited, it promoted distant liver metastasis in these mice (Wang et al., 2003). While some research studies have demonstrated a correlation between high iNOS expression, aggressiveness, and poor prognosis in patients with breast cancer (Bulut et al., 2005).

Our present results demonstrate that Indomethacin may inhibit iNOS expression depending on endogenous levels, as the administration of $50 \mu \mathrm{g} / \mathrm{mL}$ dose of indomethacin remarkably reduced the iNOS gene expression in treated group in comparison with control. Also, it was observed that $50 \mu \mathrm{g} / \mathrm{mL}$ dose of indomethacin was markedly increased survival time of treated group in comparison with control group and it was associated with poor tumor growth of treated group with $50 \mu \mathrm{g} / \mathrm{mL}$ dose of indomethacin (Figure 1). The inhibitor role of Indomethacin on iNOS expression has not been previously studied. Indomethacin is a non-steroidal anti-inflammatory drug (Glynn et al., 2010). The usage of none steroidal antiinflammatory drugs reduced the risk of breast cancer (Yiannakopoulou, 2015). The administration of this drug resulted in the inhibition of tumor growth or tumor cell proliferation (Fulton, 1984). Some researchers demonstrated Indomethacin has anti-tumor effect on some cancers such as pancreatic and lung cells (Lange et al., 2011), and it increased the apoptosis in colon cancers cell (Jazayeri et al., 2015). (Narisawa et al., 1981) reported that at autopsy, after the 15 -week treatment with indomethacin, a prostaglandin synthesis inhibitor, the colonic tumor incidence was significantly lower in treated rats than in untreated control rats. In another study, treatment of mice with indomethacin significantly inhibits tumor development (Shacter et al., 1992).

In various studies, indomethacin anti-cancer activity in inhibition of cell growth, induction of apoptosis and suppression of tumor invasion by regulating the expression of adhesion molecules have been attributed. In nude mouse model of human medullary thyroid cancer 
which treated by indomethacin the tumor volume (dimension) decreased (Carrasco-Pozo et al., 2016).

\section{Conclusion}

Finally, our results clearly demonstrated that iNOS gene expression was remarkably expressed in breast tumor tissue ( $\mathrm{p}<0.05) .50 \mu \mathrm{g} / \mathrm{mL}$ indomethacin in one hand decreased the iNOS gene expression and on the other hand reduced tumor growth. However there was no significant difference in tumor growth between the studied groups $(p>0.05)$. Further studies and research should be done such as evaluating the effects of indomethacin on the other anti-tumor immunosuppressing factor. Performing some additional tests like western blot, flow cytometry and immunohistochemistry need to complete our results.

\section{Acknowledgement}

The authors would specially like to thank Dr. Sanaz Afshari Behbahanizadeh from University of Tehran, Dr.Hossein Vaezi and Dr. Reza Qods from Azad university of Garmsar, for their helpful recommendations and advices during writing this paper.

\section{References}

Ambs, S, Glynn, SA. (2011). Candidate pathways linking inducible nitric oxide synthase to a basal-like transcription pattern and tumor progression in human breast cancer. Cell Cycle. 10:619-624.

Ambs, S, Merriam, WG, Bennett, WP, Felley-Bosco, E, Ogunfusika, MO, Oser, SM, Klein, S, Shields, PG, Billiar, TR, Harris, CC. (1998). Frequent nitric oxide synthase-2 expression in human colon adenomas: implication for tumor angiogenesis and colon cancer progression. Cancer Res. 58:334-41.

Ambs, S, Glynn, SA. (2011). Candidate pathways linking inducible nitric oxide synthase to a basal-like transcription pattern and tumor progression in human breast cancer. Cell Cycle. 10(4):619-624.

Anttila, MA, Voutilainen, K, Merivalo, S, Saarikoski, S, Kosma, VM. (2007). Prognostic significance of iNOS in epithelial ovarian cancer. Gynecologic oncology. 105(1):97-103.

Augustine, D, Sekar, B, Murali, S, Ramesh, M, Madhavan, RN, Patil, SG, Rao, RS. (2015). Expression of inducible nitric oxide synthase in carcinomas and sarcomas affecting the oral cavity. South Asian j cancer. 4(2):78.

Babykutty, S, Suboj, P, Srinivas, P, Nair, AS, Chandramohan, K, Gopala, S. (2012). Insidious role of nitric oxide in migration/invasion of colon cancer cells by upregulating MMP-2/9 via activation of cGMP-PKG-ERK signaling pathways. Clin Exp Metastasis. 29:471-92.

Barani, R, Motalleb, G, Maghsoudi, H. (2016). Evaluation of iNOS Expression in Esophageal Cancer Patients. Gastrointestinal tumors, 3(1), 44-58.

Basudhar, D, Glynn, S, Greer, M, Somasundaram, V, No, JH, Scheiblin, DA, Cheng, RY. (2018). Role of NOS2-COX2 crosstalk in tumor microenvironment of estrogen receptor-negative breast cancer and its therapeutic implications. 
Basudhar, D, Somasundaram, V, de Oliveira, GA, Kesarwala, A, Heinecke, JL, Cheng, RY, Glynn, SA, Ambs, S, Wink, DA, Ridnour, LA. (2017). Nitric oxide synthase-2-derived nitric oxide drives multiple pathways of breast cancer progression. Antioxid redox signal. 26(18):1044-1058.

Bonanni, B, Puntoni, M, Cazzaniga, M, Pruneri, G, Serrano, D, Guerrieri-Gonzaga, A, Gennari, A, Trabacca, MS, Galimberti, V, Veronesi, P, Johansson, H, Aristarco, V, Bassi, F, Luini, A, Lazzeroni, M, Varricchio, C, Viale, G, Bruzzi, P, Decensi, A. (2012). Dual Effect of Metformin on Breast Cancer Proliferation in a Randomized Presurgical Trial, J clin oncol. 30:2593.

Bonavida, B, editor. Nitric oxide (NO) and cancer. Springer/Humana Press; 2010.

Broniowska, KA, Hogg, N. (2010). Differential mechanisms of inhibition of glyceraldehyde3-phosphate dehydrogenase by S-nitrosothiols and NO in cellular and cell-free conditions. Am J Physiol Heart Circ Physiol. 299(4):1212-1219.

Bulut, AS, Erden, E, Sak, SD, Doruk, H, Kursun, N, Dincol, D. (2005). Significance of inducible nitric oxide synthase expression in benign and malignant breast epithelium:an immunohistochemical study of 151 cases. Virchows Arch. 447:24-30.

Burke, AJ, Sullivan, FJ, Giles, FJ, Glynn, SA. (2013). The yin and yang of nitric oxide in cancer progression. Carcinogenesis. 34:503-512.

Carrasco-Pozo, C, Castillo, RL, Beltrán, C, Miranda, A, Fuentes, J, Gotteland, M. (2016). Molecular mechanisms of gastrointestinal protection by quercetin against indomethacininduced damage: role of NF-KB and Nrf2. J nutrit biochem. 27:289-298.

Chen, WL, Feng, HJ, Li, JS, Li, HG. (2007). Expression and pathological relevance of inducible nitric oxide synthase in osteosarcoma of the jaws. Int j oral maxillofacial surgery. 36(6):5414.

Cianchi, F, Cortesini, C, Fantappiè, O, Messerini, L, Schiavone, N, Vannacci, A, Perna, F. (2003). Inducible nitric oxide synthase expression in human colorectal cancer: correlation with tumor angiogenesis. Am j pathology. 162(3):793-801.

Eyler, CE, Wu, Q, Yan, K, MacSwords, JM, Chandler-Militello, D, Misuraca, KL, Lathia, JD, Forrester, MT, Lee, J, Stamler, JS, Goldman, SA, Bredel, M, McLendon, RE, Sloan, AE, Hjelmeland, AB, Rich, JN. (2011). Glioma stem cell proliferation and tumor growth are promoted by nitric oxide synthase-2. Cell. 146:53-66.

Forrester, K, Ambs, S, Lupold, SE, Kapust, RB, Spillare, EA, Weinberg, WC, Felley-Bosco, E, Wang, XW, Geller, DA, Tzeng, E, Billiar, TR, Harris, CC. (1996). Nitric oxide-induced p53 accumulation and regulation of inducible nitric oxide synthase expression by wild-type p53. Proc Natl Acad Sci U S A. 93: 2442-2447.

Förstermann, U, Schmidt, HH, Pollock, JS, Sheng, H, Mitchell, JA, Warner, TD, Nakane, M, Murad, F. (1991). Isoforms of nitric oxide synthase characterization and purification from different cell types. Biochem pharmacol. 42(10), 1849-1857. 
Fulton, AM. (1984). In vivo effects of indomethacin on the growth of murine mammary tumors. Cancer Res. 44(6):2416-20.

Ganai, S, Arenas, RB, Forbes, NS. (2009). Tumour-targeted delivery of TRAIL using Salmonella typhimurium enhances breast cancer survival in mice. $\mathrm{Br} j$ cancer. 101(10):1683.

Garrido, P, Shalaby, A, Walsh, EM, Keane, N, Webber, M, Keane, MM, Sullivan, FJ, Kerin, MJ, Callagy, G, Ryan, AE, Glynn, SA. (2017). Impact of inducible nitric oxide synthase (iNOS) expression on triple negative breast cancer outcome and activation of EGFR and ERK signaling pathways. Oncotarget. 8(46):80568.

Glynn, SA, Boersma, BJ, Dorsey, TH, Yi, M, Yfantis, HG, Ridnour, LA, Martin, DN, Switzer, CH, Hudson, RS, Wink, DA, Lee, DH, Stephens, RM, Ambs, S. (2010). Increased NOS2 predicts poor survival in estrogen receptor-negative breast cancer patients. J Clin Invest. 120:384354.

Glynn, SA, Prueitt, RL, Ridnour, LA, Boersma, BJ, Dorsey, TM, Wink, DA, Goodman. JE, Yfantis. HG, Lee. DH. Ambs, S. (2010). COX-2 activation is associated with Akt phosphorylation and poor survival in ER-negative, HER2-positive breast cancer. $B M C$ cancer. 10(1):626.

Granados-Principal, S, Liu, Y, Guevara, ML, Blanco, E, Choi, DS, Qian, W, Patel, T, Rodriguez, AA, Cusimano, J, Weiss, HL, Zhao, H, Landis, MD, Dave, B, Gross, SS, Chang, JC. (2015). Inhibition of iNOS as a novel effective targeted therapy against triple-negative breast cancer. Breast Cancer Res. 17(1):25.

Grimm, EA, Ellerhorst, J, Tang, CH, Ekmekcioglu, S. (2008). Constitutive intracellular production of iNOS and NO in human melanoma: possible role in regulation of growth and resistance to apoptosis. Nitric oxide. 19(2):133-137.

Gürsoy, AA, Ylmaz, F, Nural, N, Kahriman, I, Yigitbaş, C, Erdöl, H, Kobya Bulut, H, Yeşilçiçek, K, Karadeniz Mumcu, H, Hindistan, S. (2009). "A different approach to breast selfexamination education: daughters educating mothers creates positive results in Turkey.Cancer nursing. 32(2):127-134.

Härtel, C, von Puttkamer, J, Gallner, F, Strunk, T, Schultz, C. (2004). Dose-dependent immunomodulatory effects of acetylsalicylic acid and indomethacin in human whole blood: potential role of cyclooxygenase-2 inhibition. Scand J Immunol. 60(4):412-420.

Hussain, M, Javeed, A, Ashraf, M, Al-Zaubai, N, Stewart, A, Mukhtar, MM. (2012). Nonsteroidal anti-inflammatory drugs, tumour immunity and immunotherapy. Pharmacol Res. 66(1):7-18.

Jazayeri, SB, Saadat, S, Ramezani, R, Kaviani, A. (2015). Incidence of primary breast cancer in Iran: Ten-year national cancer registry data report. Cancer epidemiol. 39(4):519-527.

Juang, SH, Xie, K, Xu, L, Wang, Y, Yoneda, J, Fidler, IJ. (1997). Use of retroviral vectors encoding murine inducible nitric oxide synthase gene to suppress tumorigenicity and 
cancer metastasis of murine melanoma. Cancer biotherapy radiopharmaceuticals. 12(3):167-75.

Kohli, M, Yu, J, Seaman, C, Bardelli, A, Kinzler, KW, Vogelstein, B, Lengauer, C, Zhang, L. (2004). SMAC/Diablo-dependent apoptosis induced by nonsteroidal anti-inflammatory drugs (NSAIDs) in colon cancer cells. Proc Natl AcadSci USA. 101:16897-16902.

Lange, A, Gustke, H, Glassmeier, G, Heine, M, Zangemeister-Wittke, U, Schwarz, JR, Schumacher, U, Lange, T. (2011). Neuronal differentiation by indomethacin and IBMX inhibits proliferation of small cell lung cancer cells in vitro. Lung cancer. 74(2):178-187.

Li, LG, Xu, HM. (2005). Inducible nitric oxide synthase, nitrotyrosine and apoptosis in gastric adenocarcinomas and their correlation with a poor survival. World $j$ gastroenterol: WJG. 11(17):2539.

Lin, SK, Kuo, MYP, Wang, JS, Lee, JJ, Wang, CC, Huang, S, Shun, CT, Hong, CY. (2002). Differential regulation of interleukin- 6 and inducible cyclooxygenase gene expression by cytokines through prostaglandin-dependent and-independent mechanisms in human dental pulp fibroblasts. J endodont. 28(3), 197-201.

Loibl, S, Buck, A, Strank, C, von Minckwitz, G, Roller, M, Sinn, HP, Schini-Kerth, V, Solbach, C, Strebhardt, K, Kaufmann, M. (2005). The role of early expression of inducible nitric oxide synthase in human breast cancer. Eur J Cancer. 41:265-71.

Massi, D, Franchi, A, Sardi, I, Magnelli, L, Paglierani, M, Borgognoni, L, Maria Reali, U, Santucci, M. (2001). Inducible nitric oxide synthase expression in benign and malignant cutaneous melanocytic lesions. J Pathol. 194:194-200.

Narisawa, T, Sato, M, Tani, M, Kudo, T, Takahashi, T, Goto, A. (1981). Inhibition of Development of Methylinitrosourea-induced Rat Colon Tumors by Indomethacin Treatment. Cancer Res. 41(5):1954-7.

Nathan, C, Xie, QW. (1994). Nitric oxide synthases: roles, tolls, and controls. Cell. 78:915918.

Nathan, C, Xie, QW. (1994). Regulation of biosynthesis of nitric oxide. J Biol Chem. 269:13725-13728.

Okayama, H, Saito, M, Oue, N, Weiss, JM, Stauffer, J, Takenoshita, S, Wiltrout, RH, Hussain, SP, Harris, CC. (2013). NOS2 enhances KRAS-induced lung carcinogenesis, inflammation and microRNA-21 expression. Int J Cancer. 132:9-18.

Pang, Y, Gara, SK, Achyut, BR, Li, Z, Yan, HH, Day, CP, Weiss, JM, Trinchieri, G, Morris, JC, Yang, L. (2013). TGF- $\beta$ signaling in myeloid cells is required for tumor metastasis. Cancer Discov. 3:936-51.

Pervin, S, Singh, R, Hernandez, E, Wu, G, Chaudhuri, G. (2007). Nitric oxide in physiologic concentrations targets the translational machinery to increase the proliferation of human breast cancer cells: involvement of mammalian target of rapamycin/eIF4E pathway. Cancer Res. 67:289-299. 
Puhakka, A, Kinnula, V, Näpänkangas, U, Säily, M, Koistinen, P, Pääkkö, P, Soini, Y. (2003). High expression of nitric oxide synthases is a favorable prognostic sign in non-small cell lung carcinoma. Apmis. 111(12):1137-46.

Qin, S, Xu, C, Li, S, Yang, C, Sun, X, Wang, X, Tang, SC, Ren, H. (2015). Indomethacin induces apoptosis in the EC109 esophageal cancer cell line by releasing second mitochondriaderived activator of caspase and activating caspase-3. Molecul Med Reports. 11(6):46944700 .

Saltzman, D, Augustin, L, Leonard, A, Mertensotto, M, Schottel, J. (2018). Low dose chemotherapy combined with attenuated Salmonella decreases tumor burden and is less toxic than high dose chemotherapy in an autochthonous murine model of breast cancer. Surgery. 163(3):509-514.

Sen, S, Jensen, K, Brennan, K, Ramadoss, S, Chaudhuri, G. (2017). Chemoprotective and Chemosensitizing Effects of Nitric Oxide and Other Biologically Active Gases in Breast Cancer Chemotherapy: Potential Implications. In Nitric Oxide (Donor/Induced) in Chemosensitizing. 169-178.

Shacter, E, Arzadon, GK, Williams, J. (1992). Elevation of interleukin-6 in response to a chronic inflammatory stimulus in mice: inhibition by indomethacin. Blood. 80(1):194-202.

Switzer, CH, Cheng, RY, Ridnour, LA, Glynn, SA, Ambs, S, Wink, DA. (2012). Ets-1 is a transcriptional mediator of oncogenic nitric oxide signaling in estrogen receptor-negative breast cancer. Breast Cancer Res. 14:R125.

Thomsen, LL, Lawton, FG, Knowles, RG, Beesley, JE, Riveros-Moreno, V, Moncada, S. (1994). Nitric oxide synthase activity in human gynecological cancer. Cancer Res. 54(5):1352-4.

Thomsen, LL, Miles, DW, Happerfield, L, Bobrow, LG, Knowles, RG, Moncada, S. (1995). Nitric oxide synthase activity in human breast cancer. Br J Cancer. 72:41-4.

Vakkala, M, Kahlos, K, Lakari, E, Paakko, P, Kinnula, V, Soini, Y. (2000). Inducible nitric oxide synthase expression, apoptosis and angiogenesis in in situ and invasive breast carcinomas. Clin Cancer Res. 6:2408-16.

Vahora, H, Khan, MA, Alalami, U, Hussain, A. (2016). The potential role of nitric oxide in halting cancer progression through chemoprevention. J cancer prevent. 21(1):1.

Vannini, F, Kashfi, K, Nath, N. (2015). The dual role of iNOS in cancer. Redox biology. 6:33443.

Wang, B, Wei, D, Crum, VE, Richardson, EL, Xiong, HH, Luo, Y, Huang, S, Abbruzzese, JL, Xie, K. (2003). A novel model system for studying the double-edged roles of nitric oxide production in pancreatic cancer growth and metastasis. Oncogene. 22(12):1771.

Xie, Q, Nathan, C. (1994). The high-output nitric oxide pathway: role and regulation.J Leukoc Biol. 56:576-582. 
Yiannakopoulou, EC. (2015). Aspirin and NSAIDs for breast cancer chemoprevention. Eur J Cancer Prevent. 24(5):416-421.

How to cite this article: Soheil Afshari-Behbahanizadeh, Samad Farashi Bonab*, Study the Effect of Indomethacin Administration on Breast Tumor Growth and Inos Gene Expression in Tumor-Bearing Mice. International Journal of Advanced Biological and Biomedical Research, 2019, 7(2), 160-172. Link: http://www.ijabbr.com/article 34472.html 